\title{
CORRIGENDUM
}

\section{Ottoman textiles and Greek clerical vestments: prolegomena on a neglected aspect of ecclesiastical material culture-CORRIGENDUM}

\section{Nikolaos Vryzidis}

https://doi.org/10.1017/byz.2017.22, Published by Cambridge University Press, 13 March 2018.

Please note the following corrections in the above article $^{1}$.

Page 92, in the Acknowledgements:

'Father Iosif, Sacristan of Vatopediou Monastery, and Father Christophoros, Secretary of Iviron Monastery'

should read

'Father Iosef, Sacristan of Vatopediou Monastery, and Father Christophoros, Secretary of Iveron Monastery'

Page 104, 1. 3: 'velvet spolia' should read 'silk spolia'

Page 107, in caption to Fig. 5: 'Rhode Island Museum of Art' should read 'RISD Museum'

Page 109, penultimate line of main text: 'an orarion in the Boston Museum of Arts' should read 'an epitrachelion in the Boston Museum of Arts'

1 N. Vryzidis. 'Ottoman textiles and Greek clerical vestments: prolegomena on a neglected aspect of ecclesiastical material culture'. Byzantine and Modern Greek Studies (2018) 92-114 